\title{
Kernos
}

Revue internationale et pluridisciplinaire de religion grecque antique

$31 \mid 2018$

Varia

\section{Encountering Pan in the Wilderness: a Small Chous in the Benaki Museum}

\section{Victoria Sabetai}

\section{(2) OpenEdition \\ Journals}

Electronic version

URL: http://journals.openedition.org/kernos/2730

DOI: 10.4000/kernos.2730

ISSN: 2034-7871

\section{Publisher}

Centre international d'étude de la religion grecque antique

\section{Printed version}

Date of publication: 1 December 2018

Number of pages: 141-165

ISBN: 978-2-87562-055-2

ISSN: 0776-3824

\section{Electronic reference}

Victoria Sabetai, "Encountering Pan in the Wilderness: a Small Chous in the Benaki Museum", Kernos [Online], 31 | 2018, Online since 01 October 2020, connection on 25 January 2021. URL: http:// journals.openedition.org/kernos/2730 ; DOI: https://doi.org/10.4000/kernos.2730

This text was automatically generated on 25 January 2021.

Kernos 


\title{
Encountering Pan in the Wilderness: a Small Chous in the Benaki Museum
}

\author{
Victoria Sabetai
}

$\Sigma \tau \eta ~ N \varepsilon \varphi \varepsilon ́ \lambda \eta$

\section{Introduction}

1 Pan, the god of wild nature par excellence, is an interstitial figure combining the features of a caprine and a man. Son of Hermes and a nymph, the goat-god was notorious for his shriek, which was able to spread panic to people and animals alike. The earliest attestation of his cult was in Arcadia, where he was venerated in built edifices since the archaic period. In Athens, Pan's worship rose after the Persian Wars. His official sanctuary was a grotto on the north slope of the Acropolis, but his cult soon spread all over Attica, where he was worshipped jointly with the nymphs. ${ }^{1}$

2 A hitherto unpublished Attic chous in the Benaki Museum, Athens, depicts a rare scene of Pan in his cave and a young woman bearing a hydria in a rocky landscape (Fig. 1-3). ${ }^{2}$ The unusual subject-matter and the choice of non-Anthesteria iconography for a chous of small size invite further study. In what follows I argue that the encounter of the caprine god and the mortal in the wilderness visualizes the liminality of the latter's status as a nubile maiden, and that this pictorial theme was conceptually related to the Dionysiac festival of the Anthesteria.

\section{The Chous and its Scene: Towards an Interpretive Approach}

3 At the left side of the scene Pan appears at the opening of his cave, only half of which is rendered as an arched opening in frontal view. ${ }^{3}$ Only his torso is depicted; the rest of his body goes off the frame. He emerges from his cave in a reclining, almost crawling 
position, resting on his left hand, while raising his right arm slightly; he has a humanoid form, in accordance with the prevailing type of the Classical period, but his facial features retain some degree of bestiality apparent in the pointed ears, high horns springing from a shaggy head, wide-open eyes, snub nose, thick-lipped mouth and wispy, goat-like beard. ${ }^{4}$

4 Pan's gaze is fixed on a young woman holding a hydria, who rushes towards a rock that is depicted as a vertical stripe. The surface is extensively damaged here, but a stream of running water could be hypothesized as flowing from the rock, probably drawn in added colour, which has now faded. Yet, even if the painter omitted the stream of water, we may still perceive the scene as comprising one, for classical vase-painters on occasion imply the spring without representing it. ${ }^{5}$ The striding woman wears a belted chiton with blousing and overforld, and is adorned with a necklace; she clasps the pleats of her garment in a feminine gesture and advances to the rock while looking back. ${ }^{6}$ She is featured in larger scale than Pan, which highlights her protagonistic role in the image.

5 The female's face is abraded, which makes it difficult to understand the odd rendering of her head's contour. This forms a bulge at the forehead and a pointed edge above the nape of her neck: does it denote something worn on the head, or is it a type of coiffure? Reconstructing the figure with a tyle, i.e. a ring-shaped pad used to support the filled vase on the head, would be an unlikely solution, for if it were so, the edge should protrude higher up, closer to the crown of the head. It seems more plausible to interpret this rendering as the edge of a loose, chin-length, square coiffure, as on a funerary stele from Paros dated ca. $440 \mathrm{BC}$, which depicts a young girl at the threshold of adolescence. ${ }^{7}$ The figure-type of the woman wearing a square coiffure is particularly favoured by a painter of the third quarter of the fifth century $B C$, the Hasselmann Painter, who further depicts her at a fountain or rocky spring (Fig. 5). ${ }^{8}$

6 Although Pan's iconographic association with a cave, as on our chous, recalls explicitly his cult places all over Attica, in fifth-century vase-painting he rarely features in such a space. Pan in his cave prevails in fourth-century art and mainly in votive reliefs depicting him in the company of nymphs and worshippers, but he does not, as here, appear alone. ${ }^{9}$ As regards our female figure, the first thought would be to identify her with a nymph fleeing Pan's amorous intentions. The testimonia mention that the caprine god was enamored of the nymphs Echo, Pitys, and Syrinx. Yet, although Pan's love for these nymphs is popular in literature, there are no certain identifications of such scenes in visual art, and it seems that there was no established iconographic type for their representation. ${ }^{10}$ Further, the goat-god shows no intention of pursuing the striding woman, quite the opposite in fact, as suggested by his reclining posture and appeasing gesture of address. Pan, an epiphanic god par excellence, makes a rather calm apparition before the surprised female here. ${ }^{11}$ To be sure, this does not bring at all to mind his amorous chases of young herdsmen, as on the famous krater by the Pan Painter, which antedates our chous by almost half a century. ${ }^{12}$ Since Pan was involved with youths already in the early years of the fifth century BC, we may classify our scene as an encounter between a divinity of wild nature and a mortal. Thus, our image does not unfold in the realm of mythological narrative but transports us to the sphere of imaginary contact between deities and mortals.

7 If not a nymph, could our woman be a worshipper like those frequenting his caverns? The archaeological record of Attic caves consecrated to Pan and the nymphs offers 
plentiful evidence of cult activity, despite the fact that these locales are often far from inhabited areas and usually on remote mountain cliffs with difficult access. ${ }^{13}$ The presence of young worshippers in the caves is attested by votives, most diagnostic of which are the miniature nuptial loutrophoroi, which recall the wedding bath ${ }^{14}$ Their vessel-type and small size reveal their function as token offerings associated with the prenuptial phase. The presence of maidens in the caves is further documented by finds of krateriskoi, a characteristic vase-type associated with female maturation rituals in the sanctuaries of Artemis at Brauron and Mounichia. ${ }^{15}$ Ephebic dedications of this sort ascribe an initiatory role to the cult of Pan and the nymphs that is not restricted to Attica. A kouretic function for Pan has also been surmised in his native Arcadian sanctuary at Mount Lykaion, where the votives, of the late-Archaic period, depict hunters, men carrying sacrificial animals and Pan's father, Hermes, the quintessential intermediary deity and overseer of maturation rituals. ${ }^{16}$

8 Hydriai like the one carried by our female figure are not a characteristic vase-type in the cave assemblages. They occur rarely and most are miniatures dating in the fourth century BC. The woman on our chous does not hold a small effigy of a hydria but a fullsize one; nor does she show any intention of entering the cave to offer her water-vessel to the nymphs, deities more closely linked to water than Pan, but who are actually not depicted here. Thus, ours cannot be a cult scene transcribing the ritual reality of a worshipper offering a token hydria to the cave deities. Our woman is actually out in search of water, as suggested by her still empty vessel and her marching towards the rock in the hope of a spring. ${ }^{17} \mathrm{~A}$ lone young woman in search of water a long way from her city's famous fountain-buildings, such as the Peisistrateian Enneakrounos in the Agora, may suggest that our woman is not where she should be. ${ }^{18}$ She must have lost her way in the wilderness, therefore the image on our chous is indeed an unexpected and surprising one. It should be noted that our maiden is not in the space of the idyllic orchard either. This kind of landscape visualizes the cultivated chora around the city and is depicted as fruit-bearing trees framing formulaic maidenly activities such as ball-playing and fruit-collecting. ${ }^{19}$ In contrast, our maiden is in a wilderness denoted by barren rocks and controlled by potentially frightful beings, a little bit like Little Red Riding Hood walking through the woods while the Big Bad Wolf stalks her behind trees (Fig. 6). This famous fairy-tale has been seen as transcribing the experience of a puberty rite with the girl leaving home, entering a liminal state and transforming into an adult woman in the end. Anthropologists further relate this type of tale with "animal bridegroom" stories, such as Beauty and the Beast, where the wild nature of the male is finally tamed by the power of female sentiment. ${ }^{20}$

9 The maiden intruding unawares into the interstitial realm of Pan's wilderness pictures a cultural concept with possible roots in ancient folk tales, that of the girl at the eve of erotic maturity who may face peril when at this transitional life-phase. And who is more appropriate to appease the anxiety inherent in liminal situations than Pan, master of all fears? ${ }^{21}$ In what follows I analyze our image on the level of artistic representation, in particular within the series of images with hydria-bearers, on the one hand, and with Pan, on the other. The discussion seeks to understand the meaning of a scene visually collocating a hydriaphoros with Pan's wild realm, in which, however, the goat-god appears as a mild divine force. The issue is more complex than readily apparent also because the support of our image is not a hydria "echoing" the vase 
carried by the woman, but a chous, a ritual vase-type associated with childhood and with the sphere of Dionysos.

\section{The Semantics of Hydriaphorai} iconography has been intensely debated in recent years because of the issues it raises regarding the identity of the women, the meaning of the subject and the approaches that are appropriate for its interpretation. ${ }^{22}$ The fountain corpus is rich, evolves over time, presents serious and comic variants and is intertwined with other related series of images, especially those of women washing at a fountain or louterion..$^{23}$ Anonymous but also mythological maidens, such as Polyxene and Amymone, were cast as hydriabearers at the fountain in a narrative context. In the Archaic period the emphasis is on elaborate fountain buildings, richly dressed young women in groups of peers and a festive ambiance; occasionally gods, in particular Dionysos and Hermes, are present. In the Classical period women bearing hydriai acquire erotic hues by appearing in the company of Eros and Aphrodite or in settings associated with beautification and games of a divinatory character which hint at love and marriage. After the mid-fifth century $\mathrm{BC}$, the theme spreads to small-sized vessels, mostly lekythoi, containers of unguents. The collectivity imparted by the archaic scenes gives way to single maidens with hydriai, while the fountain buildings are replaced by water spouts of the simplest form. These minimal visual signs for channeled water may occasionally be absent, because the emphasis of classical art is no longer on the setting nor on the activity of water-fetching, but on the ethos and status imparted by the figure-type of the hydriaphoros, which conveys ideas of beauty, seduction and nuptiality.

Women at the fountain have been occasionally seen as slaves or hetairai in text-driven interpretations focusing on what the literary sources tell us about some of the realities of water-fetching. Yet, although the fountain scenes depict women in an activity inspired from lived experience, they are not quotidian representations tuned in the mode of documentary realism, but formulaic images reflecting the social imaginary of the Greeks and in particular their cultural concepts of ideal femininity (Fig. 7). ${ }^{24}$ The reality underpinning fountain imagery was associated with the various festive hydrophoriai that articulated Greek social and religious life. ${ }^{25}$ These offered the sight of elaborately dressed citizen women to the male gaze and maidens, in particular, could be seen, encountered in the open and desired by men (Fig. 8). The short-termed coexistence of the sexes in public space eventually fuelled poetry, as well as visual and cultural imagination, not only in ancient Greece but in the Mediterranean basin across the centuries. Even today, many songs and poems talk about the beautiful maiden who left home to fetch water and was courted or kissed at the fountain, as a prelude of the marriage to follow. ${ }^{26}$ By the third quarter of the fifth century BC, the date of our chous, the wedding metaphors underpinning fountain imagery and the connotations of the female hydria-carrier were so self-evident to everybody, that a scene with a hydriaphoros could be elliptical, with no need of the narrative context or the detailed fountain setting of earlier times. Thus, our female is depicted in the hydriaphoros-type 
because she is a nubile maiden and our scene may be devoid of narrative, but is not devoid of content. Yet, the maiden is not cast as a fountain- but as a mountain-girl for she is seeking water at a rocky spring in the wilds, away from urban culture. ${ }^{27}$ The painter of our chous visualizes the hydriaphoros' intermediary status between maidenhood and womanhood by depicting her with a divinity of the wild nature. Pan, a god with dual nature able to cause fear, is most appropriate to oversee the interstitial sphere, which is by definition marked by change and anxiety. Yet, although Pan personifies terror, his rather calm appearance at the sight of the hydriaphoros here is worth noting. This is a development of the Classical era that became associated with the imagery of the nubile woman. It should be best understood in the wider context of "domesticating" mixed beings, such as, e.g., the satyrs, creatures of the Dionysiac realm to which Pan is not alien. ${ }^{28}$

13 Let us now take a closer look at the iconographic background of the goat-god and examine in particular his relationship to caves, women, the prenuptial and the Dionysiac realms.

\section{Pan, Caves, Females}

14 As mentioned above, Pan's function in Attic cult and religious mindset followed the historical changes brought about after the Persian wars, when he became a cave-god and his cult and iconography underwent remodelling. Why was he associated with caves? ${ }^{29}$ This took place first in cult and much later in art, where the contexts in which he appears originally are actually Dionysiac, as we shall see.

On the level of cult, the cave may have been adopted for its association with Pan's mythic genealogy and birth, as well as due to its ambiguous double character as a topos of wilderness and nurturing home. ${ }^{30}$ In Greek mythology and thought, the cave could be a space of isolation, but also of divine births, as well as of illicit erotic encounters. Its marginal status and function as locus mirabilis made it the perfect abode for a divinity mediating between the animal and the human. As an interstitial figure of wild nature Pan in his cavern could visualize the eschatiai, the remote wilderness extending beyond the civilized space of the polis, ${ }^{31}$ a liminal space associated with concepts of initiatory separation at the passage to adulthood. Images such as Pan overlooking a hydriaphoros wandering in a rocky landscape, or a woman taking a (prenuptial) bath in a cave should be inscribed into this conceptual framework. ${ }^{32}$ Thus, the Benaki chous creates an image of the crossing of age boundaries as a journey in the wilderness that stands conceptually at the opposite end of the oikos and the polis. Timing is also important: the girl's unwitting intrusion into the goat-god's realm could have provoked his disturbed epiphany if coinciding with his noontime rest. ${ }^{33}$ Pan's reclining position on our chous may in fact suggest that the maiden's trespassing into his sacred space took place while he was sleeping in his cave. Luckily, his benevolent attitude towards maidens helped prevent his wrath.

Pan's associations with caverns and maidens may be further explained by his cultic relations with the cave-dwelling nymphs after $490 \mathrm{BC}$. These semi-divine females thought to inhabit free nature were also considered bridal archetypes. The word nymphe signified the female at the stage between maiden and mother, hence the nymphs also functioned as the mythological equivalent of the Greek marriageable maiden. ${ }^{34}$ Still, Pan's grotesque figure and animalistic lust, resulting in his being called 
duseros, an unsuccessful lover, seem incompatible with the chastity of the nymphs. To explain their relationship, Ph. Borgeaud argued that bestial Pan and the charming nymphs represent two binary poles, both associated with the permeable boundaries and ambiguity of the prenuptial phase: to the purity of the nymphs is juxtaposed Pan's extravagant and distorted sexuality. Just as a virgin goddess like Artemis protects childbirth, so duseros Pan, in a relationship of complementary opposition, "prepares, introduces and initiates into marriage". ${ }^{35} \mathrm{~A}$ number of testimonia reveal the associations between Pan's cave, nuptial rites, and lust in Greek popular imagination. Pan was further named "erotikos" and his assaults on the nymphs "Panos gamoi". ${ }^{36} \mathrm{His}$ benevolent attitude towards girls and marriage is also at the background of Menander's comedy Dyscolos (316 BC), where the caprine god rewards a pious maiden by causing a wealthy youth to fall in love with her. The stage is his cave at Phyle in Attica and the celebrations described in the play have been interpreted by Ph. Borgeaud as prefiguring marriage, with Pan as a god of erotic desire that is mixed with anxiety. ${ }^{37}$ Thus, although Pan is a potentially frightful deity, he may appear as a positive figure regarding erotic issues in the art of the Periclean period and later. Love and marriage awaits the maiden at the crossing to maturity, as suggested by the imagery of both our chous and the Dyscolos.

17 Since Pan was associated with caverns in cult and literature, why does he appear in them rarely in fifth-century vase-painting? Caves are infrequently depicted in this medium in general and, when they do appear, they look more like a rocky shed than a cave. ${ }^{38}$ Minor painters of the early fifth century BC depict such rocky formations in contexts associated with frightful creatures such as, e.g., Lamia, the Cyclops Polyphemos, Circe, and Python at Delphi. A reclining Dionysos with his thiasos is also occasionally depicted under such sheds. The associations of monsters and Dionysos with caves should be probably seen as stressing their alterity and wild nature ${ }^{39}$ They are appended to the figures not as landscape elements but in order to reinforce their characterization as transgressive beings alien to urban space, which is also the case of Pan. ${ }^{40}$

18 In the early fifth century $\mathrm{BC}$, when Dionysos and some monsters are featured in caves, Pan is not, despite the fact that he receives cult in them. Yet, he appears with the god and his thiasos in sympotic settings, which suggests some overlap between the spheres of Dionysos and Pan prior to, or roughly contemporary with, the latter's reinvention as a cave god. ${ }^{41}$ An example of Pan's association with the Dionysiac realm is the symposion scene on the krater in Amsterdam (2117) depicting Pan as a flute player among satyrs. ${ }^{42}$ Further, on a lekythos by the Beldam Painter two Pans resembling silens flank a big krater, one holding a lyre, the other a cup ${ }^{43}$ while on an eye-amphora by the Red-Line Painter Pan and a woman appear between vines. ${ }^{44}$

Depictions offering an explicit link between Pan and the sphere of Eros, Aphrodite, and the bride begin in the second quarter of the fifth century $\mathrm{BC}$ peaking in the fourth century $\mathrm{BC} .{ }^{45}$ On a lekythos in Chicago, Pan meets Eros; each is followed by a goat and a rooster respectively, which function as the deities' alter-egos on the animal level. ${ }^{46} \mathrm{By}$ ca. $430 \mathrm{BC}$ the Phiale Painter decorates a cup with the caprine god facing Aphrodite herself. ${ }^{47}$ Pan's association with erotic unions is further attested by his occurrence in late fifth and early fourth-century hierogamia scenes of Dionysos and Ariadne ${ }^{48}$ as well as of Poseidon and the hydriaphoros Amymone..$^{49}$ Caves are not depicted in these images, but they feature prominently in fourth-century anodos-scenes where Pan looks on a 
prototypical bridal female emerging from the earth in a rocky cavern. Scholarly opinion has pointed to the initiatory meaning of this type of imagery, whereby Pan and Hermes mediate the passage of the maiden to the upper world. ${ }^{50} \mathrm{As} \mathrm{Ph}$. Borgeaud saw, Pan's presence in these scenes should not be merely thought of as a visual reference to pastoral land, but rather as one that classifies the scene as supernatural. ${ }^{51} \mathrm{~A}$ mythological creature which is half-human, half-beast, as well as semi-divine, perfectly visualizes transitional notions and may reasonably appear as an observer of initiatory type imagery.

Pan's appearance with nubile females spreads further to other workshops and media (see $\mathrm{n} .22$ and below) from the fourth century BC onward. Remarkable in this context is a Paestan lekythos with Pan offering the erotic gift of a hare to an elaborately dressed and adorned maiden leaning towards him (Fig. 9). ${ }^{52}$ Mirrors, wedding gifts which ended up in female graves, share on occasion the same artistic language and subject-matter with vase-painting. Pan is a favourite subject depicted on them, either alone or with Eros and women. Although commonly termed nymphs, the latter could be also brides, their "Aphrodisian" appearance and fusing of identities suggesting that they were thought of as facets of the ideal nubile female. Of particular interest for the associations of Pan with the prenuptial phase, documented further by the loutrophoroi from his caves, is a mirror depicting the goat-god with a woman on its cover and the bath of a female at a fountain under his eyes on its interior (Fig. 10a-b). The setting is a cave, with Pan's head featured on its walls, together with wreaths that mark the festive occasion..$^{53}$ The motif of the bathing female is further associated with Pan on two votive reliefs of the Hellenistic and Roman eras from Ionia. ${ }^{54}$ Examples of this kind show that Pan's divine manifestations to nubile maidens unfolded under his beneficial eye from the Classical era onward, despite the fact that they took place at an interstitial and thus potentially dangerous space. Such a mood is also imparted by our scene, which is a thematic precursor of later variants on mirrors.

\section{Pan and the Maiden on a Chous: the Context of the Anthesteria}

What is the correlation between an iconographic topos exemplifying coming of age, and the vase-type it decorates? The wine-jug known by the name of chous is related to the oldest Attic Dionysiac festival, the Anthesteria, central to which were the ritual celebration of the advent of Dionysos on the occasion of the first consumption of the year's new wine. A number of problems surround the study of this spring festival, due to the fragmented and heterogeneous nature of the evidence. ${ }^{55}$ The literary sources suggest that infants played a prominent role in the Anthesteria. This was highlighted by the crowning with flowers of three-year-olds, whose initial participation in the festival functioned as a rite of passage to childhood. Yet, the ritual festivities did not concern solely small but also older children, as suggested by iconographical evidence of the late fifth century BC. ${ }^{56}$ Thus, the Anthesteria emerges as an occasion for multiple transitions whereby three-year-olds, but also older boys and adolescents were initiated in the cult of Dionysos by virtue of celebrating the successful completion of an age cycle and preparing to enter the next..$^{57}$

The testimonia support a connection between the shape of the chous and the Anthesteria, as the former was used in the wine contest that took place on the day of 
the Choes and was subsequently wreathed. ${ }^{58}$ Scenes on the choes themselves often depict a wreathed chous in the background in a self-referential way and as marker of the festival. As to the correlation between the imagery on the choes and the Anthesteria, most scholars distinguish between large and small jugs. The large ones (over $15 \mathrm{~cm}$ ) are thought irrelevant to the ritual for their imagery appears varied and undifferentiated from images on other shapes, while the small, commonly depicting infants in a highly conventionalized iconography, are seen as reflecting aspects of the festival. The infants are usually male, but girls of various ages also occur. ${ }^{59}$ Thus, the Benaki chous is certainly connected to the Anthesteria through its shape and small size. Its choice of theme requires further analysis in order to understand whether and in what way it may have been associated with the festival. ${ }^{60}$

The degree to which the imagery decorating the small choes refers to cult or had a sacred significance has been a matter of scholarly debate. The chief concern was to determine if and in what way the images on the beakers could be used as a documentary source for the Anthesteria that would allow to assess the reliability of the - mainly later - testimonia and fill in whatever gaps remain in our reconstruction of its ritual events. Yet, although several images on small choes stereotypically depict babies wearing amulets among paraphernalia directly related to the festival, such as festival food, tables, bunches of grapes, ${ }^{61}$ and wreathed wine-jugs, the prism through which the ritual is refracted in art is far from straightforward. In fact, besides the elements connoting the festival's realities, several beakers depict also toys and pets, which allude to the realm of the child in a more general manner and help create an ambiance of happy pastimes. ${ }^{62}$ Furthermore, supernatural or mythological beings such as Nikai, Eros and satyrs, as well as activities such as goat-riding, demonstrate that there was also plenty of room for imaginary themes that were usually associated with the Dionysiac realm. ${ }^{63}$ Iconographical fiction of this kind suggests that the scenes on the small choes do not offer any literal representations of the Anthesteria rituals. Rather, they are images imparting a religiosity ${ }^{64}$ that was particular to a Dionysiac festival concerned with issues of maturation via wine metaphors of new growth and transformation. ${ }^{65}$ As the grape juice transforms to fermented wine that has to be consumed within a framework of rules nullifying its toxic potential (i.e. mixed with water at the symposion), so the child grows to adulthood by learning to conform to the polis' role models and cultural ideals. In this line of thought, the depiction of a theme associated with the end of female adolescence, as on our chous, is no surprise, despite the fact that it deviates from the usual repertory of the small jugs in that it does not depict babies nor boys, but a maiden soon to be transformed by marriage under the sign of Nuptial Pan. Thus, although our beaker's imagery may at first sight seem irrelevant to the Anthesteria because it lacks any elements signaling its rituals in a straightforward manner, it is, nevertheless, conceptually related to it in that it tackles the issue of maturation. Note that besides being the god of wine, Dionysos oversaw also the development of young people and was regarded as a guarantor of their social integration into polis life and culture. ${ }^{66}$ What is more, the Benaki chous offers affirmative evidence that in Periclean Athens maturation of the female paides was also an issue at the Anthesteria, which accounts also for the juglets that depict small girls crawling or with paraphernalia signalling this festival. The lower percentage of their appearance on the choes has puzzled scholars, but may be interpreted by considering the findspots of beakers as well as elements of ideology concerning females. Some girls' graves may have been furnished with other, more gender-related types of gifts instead 
of juglets, such as vases or figurines associated with their prospective matronal role, which may have been deemed more apt for females than a token of their participation in a wine festival. It is further possible that such tombs may have comprised choes featuring boys in order to recall the male members of the girl's oikos, or even to forecast the baby-son they will never bear due to their premature death. ${ }^{67}$

Thus, it seems safe to infer that girls were also presented with choes-jugs at the Anthesteria. The choice of a prenuptial theme featuring a divinity of mixed nature that became gradually associated with maidens, Eros and the Dionysiac realm in the Classical period makes our chous a suitable gift to a living girl on the occasion of completing an age cycle or in the hope for successful maturation; ${ }^{68}$ and, to a dead one as a memento of a missed life-stage..$^{69}$ It implies further that prenuptial iconography was not unrelated to concepts of central importance at the Anthesteria.

This type of analysis can be extended further to the large choes. Although most scholars associate only small examples with the Anthesteria, it is possible that some large ones, at least, were also related to the festival. ${ }^{70}$ Thus, we may ask whether other large choes depicting genre themes with paradigmatic prenuptial value, such as naked brides in the company of Eros and a youth (the groom), weddings, Muses, nymphs, legendary brides like Helen, and girls washing themselves were actually meant to be gifts to maidens on the occasion of their participation in the festival, or upon completing an age-grade at about that time. ${ }^{71}$ The same can be said for some large choes with "male" subjects of exemplary character which may be regarded as appropriate for older boys celebrating the spring festival. For example, iconographic themes such as the depictions of the Tyrannicides, who were the model heroes of the Athenian polis, or of the Panathenaic races, may have appeared on choes not as random scenes but because they exemplify cultural ideals with educative and ethical values for the ephebes taking part in the Anthesteria. ${ }^{72}$

It follows that equally important to reconstructing the rituals taking place at the Anthesteria festival is understanding which iconographic themes were conceptually related to it by functioning as visual metaphors. On the occasion of a Dionysiac celebration concerned with maturation gender roles were re-affirmed and marriage as an adult role model for the Athenian maiden could be implied with scenes such as Pan encountering a hydriaphoros in the wilds.

\section{Conclusion}

The Benaki chous provides one of the earliest depictions of Pan's benevolent epiphany on the occasion of a nubile maiden's metaphorical journey to maturation. The cultural perception of coming of age as a borderline experience is visualized as searching for water in the eschatiai, a realm of danger and fear controlled by Pan. The territorial liminality of the cavernous setting and the depiction of the woman as hydriaphoros ascribe the scene special nuances of erotic initiation. Our scene anticipates fourthcentury imagery on vases, but also on other media, as well as the plot of Menander's Dyscolos. It attests to the gradual remodelling of Pan from bestial to benevolent in the Greek religious mindset and further recalls those Hellenistic inscriptions that name him theos epekoos, a god who lends an ear to human prayers and appears in moments of danger to offer assistance. ${ }^{73}$ 
The iconographic encounter of Nuptial Pan and the exemplary hydriaphoros maiden in a non-representational, conceptual image, reflects the ancient belief that Pan was a liminal figure, and thus pertinent to oversee female age transitions. Their combined appearance on a shape recalling Dionysiac cult may seem less enigmatic, if the associations between the Anthesteria and this festival's concern with new growth via wine metaphors are taken into consideration.

In sum, the Benaki chous is related to Dionysos and to the Anthesteria via both its shape-type and prenuptial theme. Its small size and good state of preservation suggest that it may have ended in the grave of a girl, whom it visualized as a nubile hydriaphoros maiden under the beneficial eye of Nuptial Pan, a wild deity who is cast in a civilized guise from the latter part of the $5^{\text {th }}$ century BC onwards. Pan's philanthropic facet when it comes to maidens and marriage makes this interstitial deity a mediator between wild nature and civilization. The theme of civilizing nature's wild forces imbues the scene on our chous, which, by virtue of its shape-type, recalls analogous notions informing also the festival of the Anthesteria. ${ }^{74}$

\section{Illustrations}

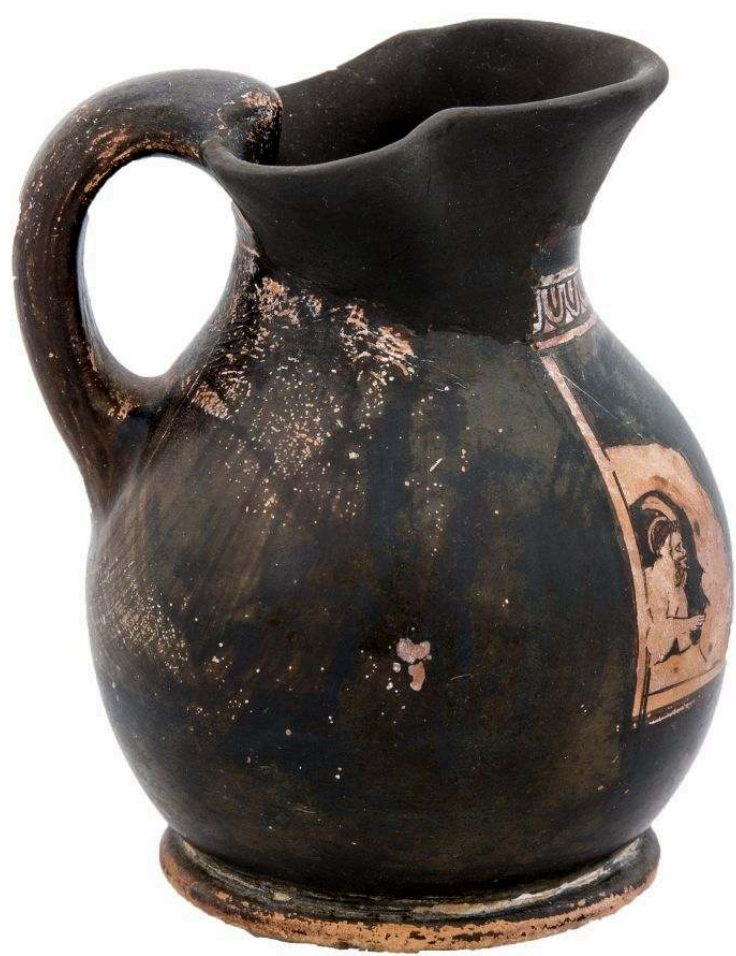




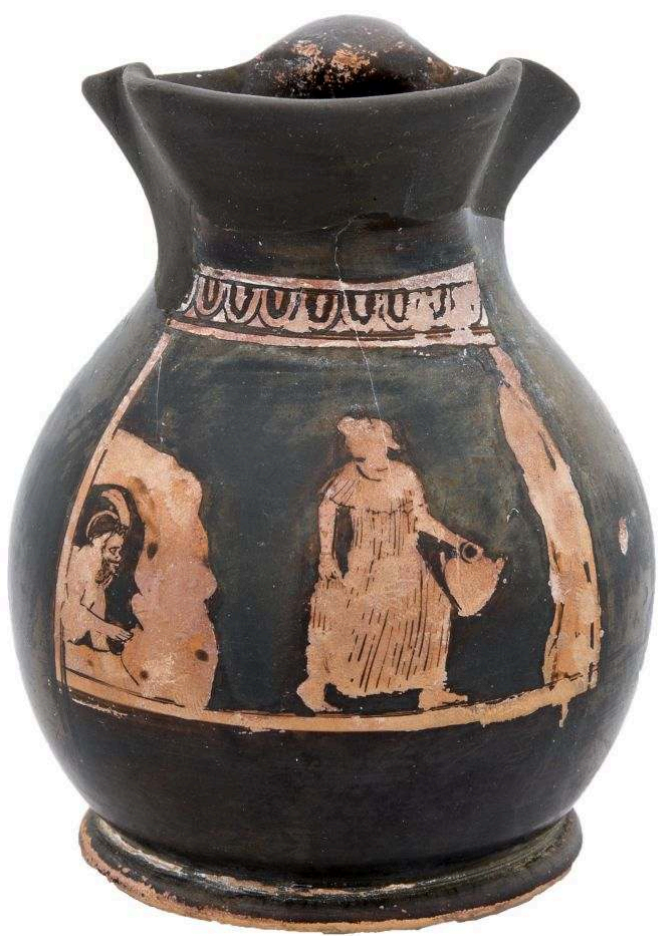

Figs. 1-2. Red-figure chous, Athens, Benaki Museum inv. 38145. CREDIT LINE: COURTESY OF THE BENAKI MUSEUM.
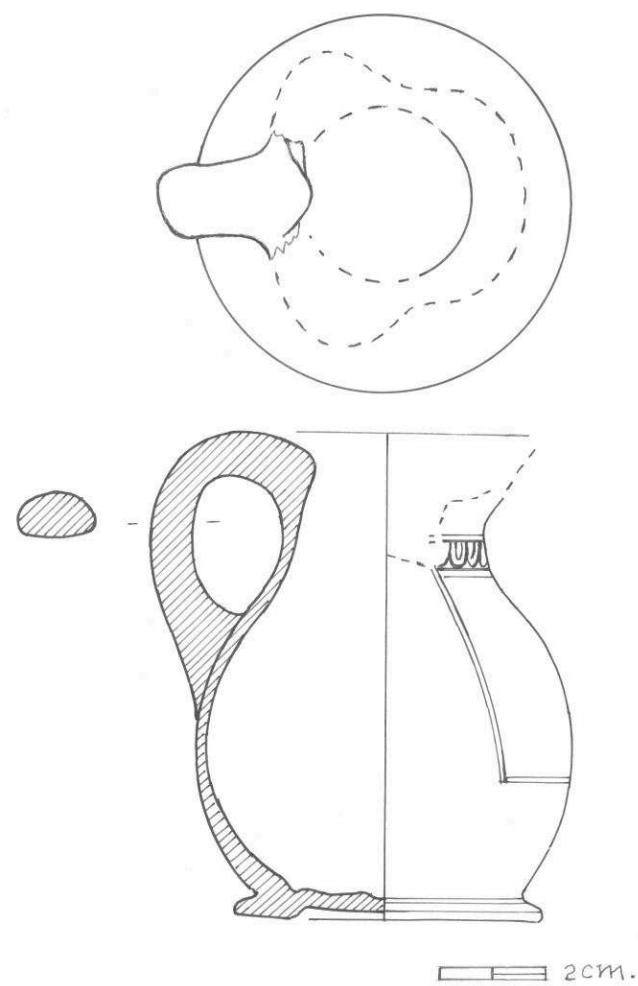

Fig. 3. Red-figure chous, Athens, Benaki Museum inv. 38145. Line drawing by A. Dringopoulou. CREDIT LINE: COURTESY OF THE BENAKI MUSEUM. SCALE 1:2. 


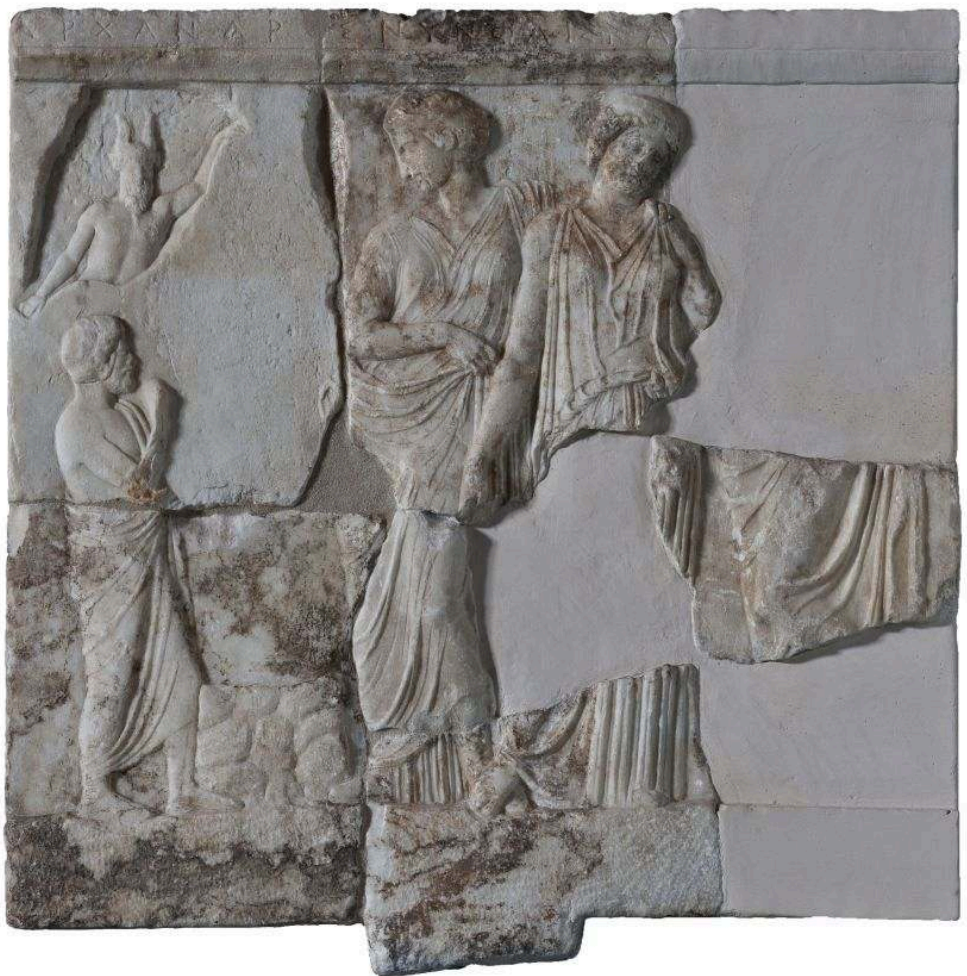

FIg. 4. ARCHANDROS RELIEF, ACROPOLIS MUSEUM EAM 1329.

CREDIT LINE: COURTESY OF THE ACROPOLIS MUSEUM. PHOTO BY SOKRATIS MAVROMMATIS.

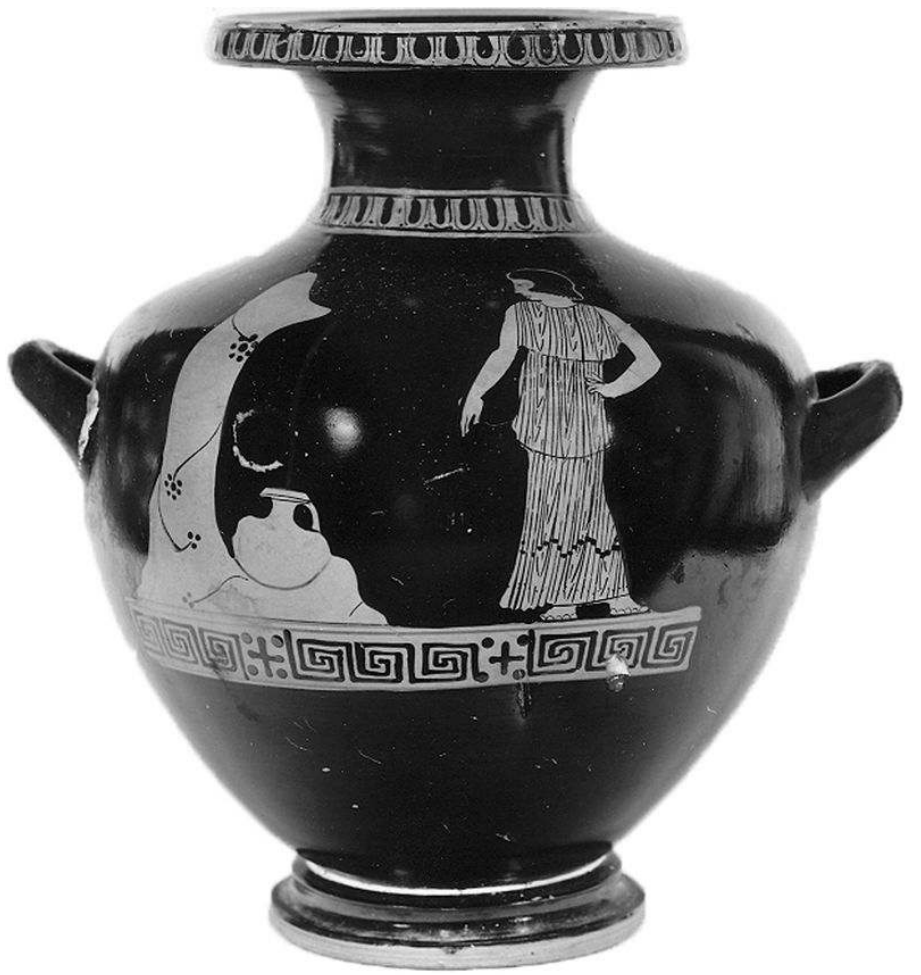

Fig. 5. Hydria, Auckland Museum Inv. 32749 (ARV 1139, 4).

From sabetal (2009), p. 112, fig. 10. 


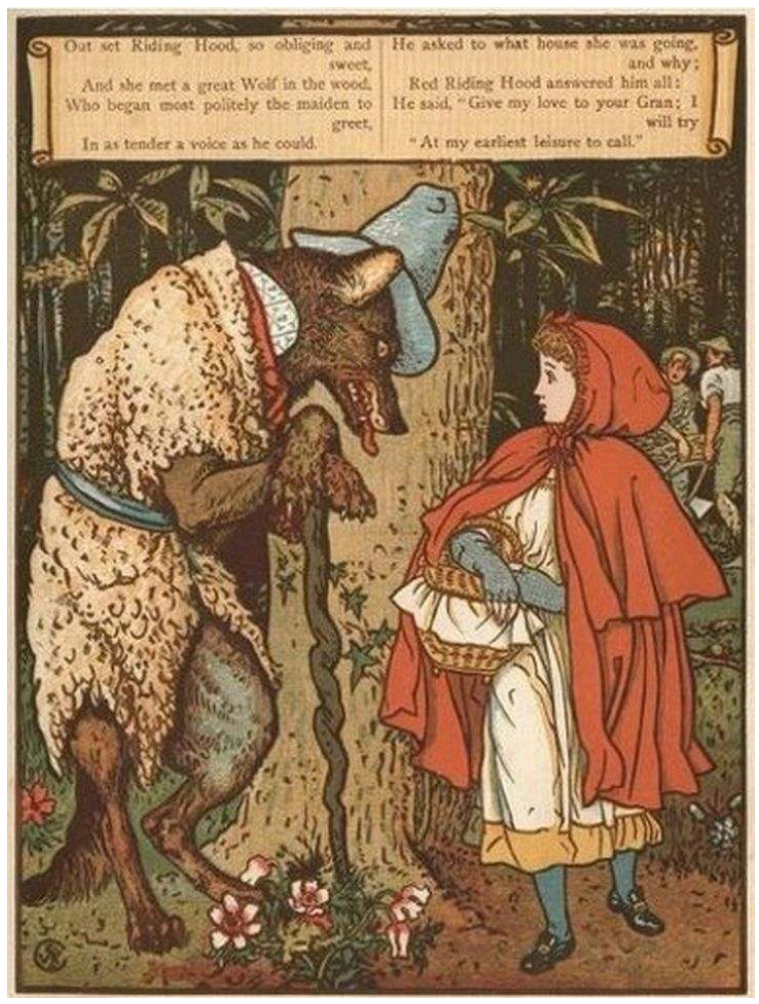

Fig. 6. Little Red Riding Hood. Color-printed illustration for Children's Books by Walter Crane, London, 1875

(HTTPS://ARCHIVE.ORg/DETAILS/LITTLEREDRIDINg00CRAN).

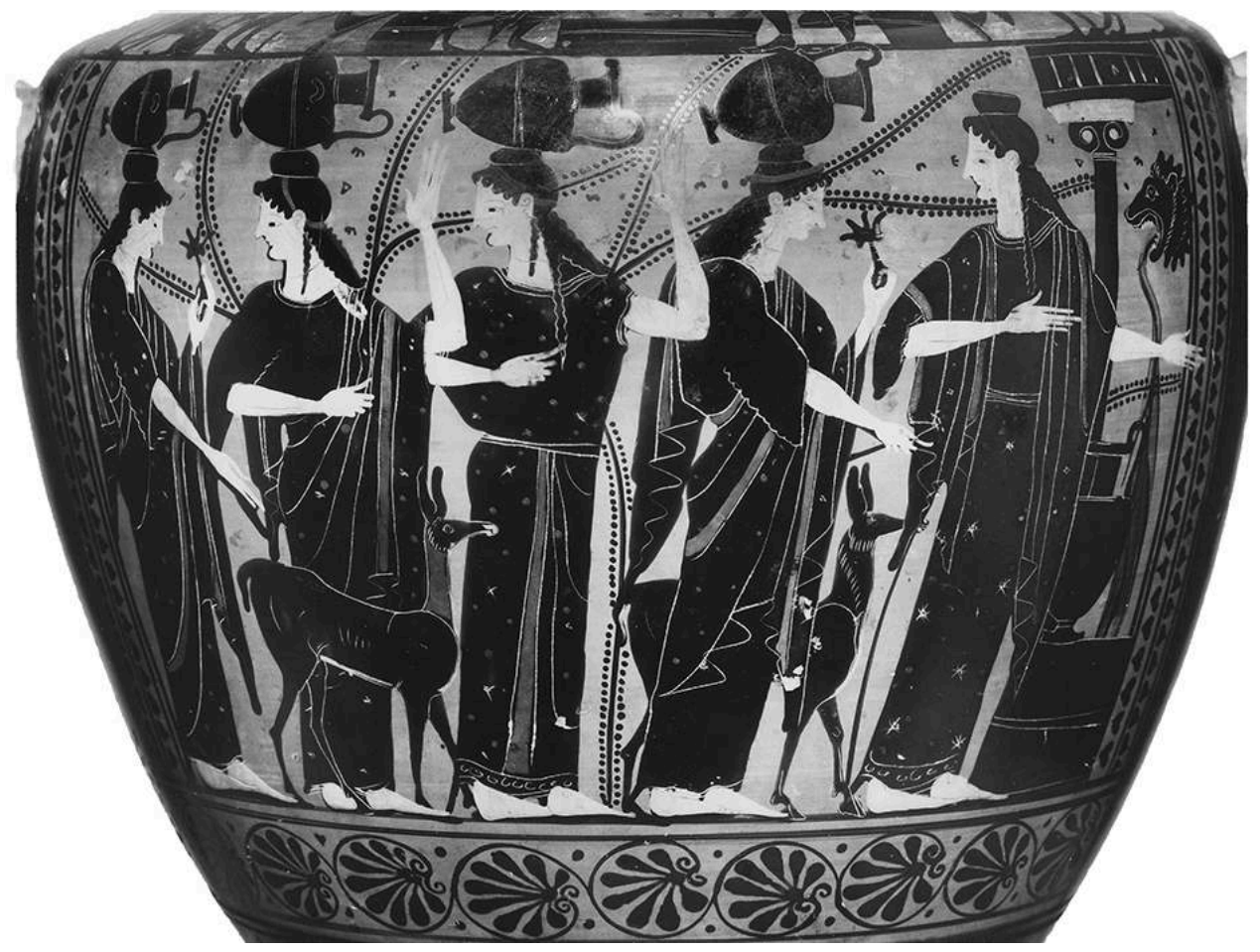

FIg. 7. HYDRIA, BERLIN, ANTIKENSAMMLUNg INV. F 1908.

CREDIT LINE: ANTIKENSAMMLUNg, STAATLICHE MUSEEN ZU BERLIN - PREUSSISCHER KULTURBESITZ. 


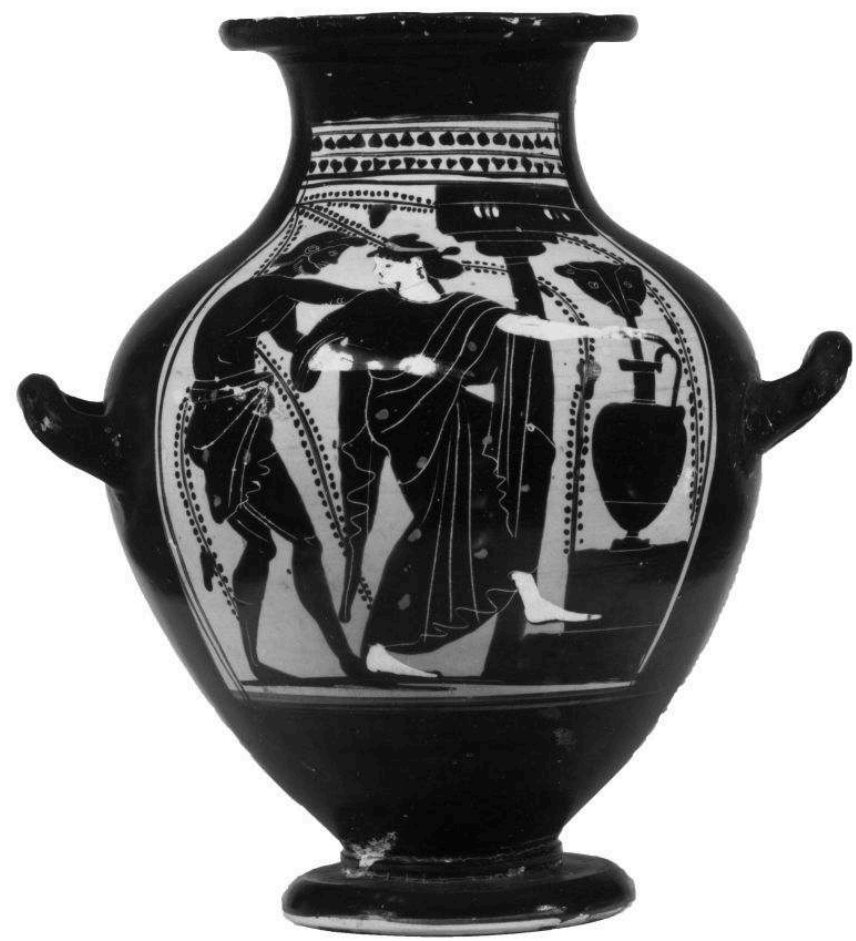

FIg. 8. HYDRIA, BERLIN, ANTIKENSAMMLUNg INV. F 1910.

CREDIT LINE: ANTIKENSAMMLUNg, STAATLICHE MUSEEN ZU BERLIN - PREUSSISCHER KULTURBESITZ.

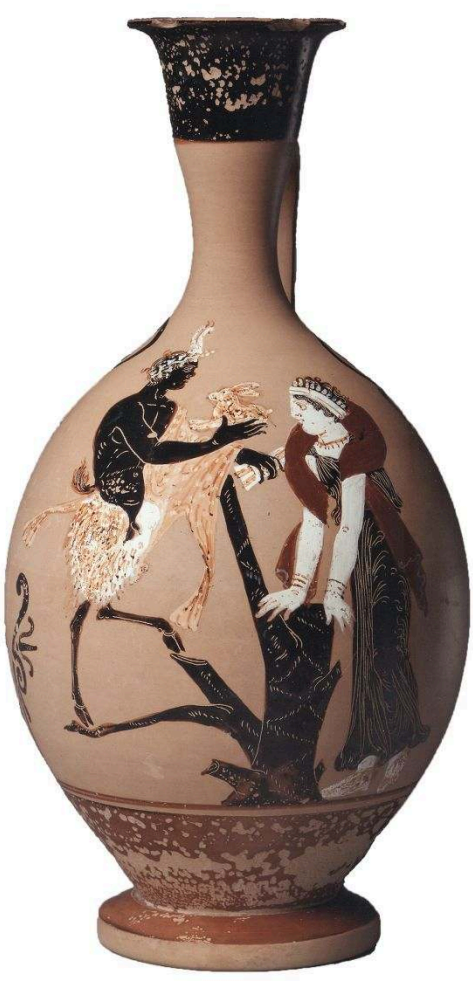

Fig. 9. PAESTAN LEKYTHOS, CLEVELAND MUSEUM OF ART 1985.1 FROM CAMPANIA, ITALY. JOHN L. SEVERANCE FUND.

CREDIT LINE: COURTESY OF THE CLEVELAND MUSEUM OF ART. 

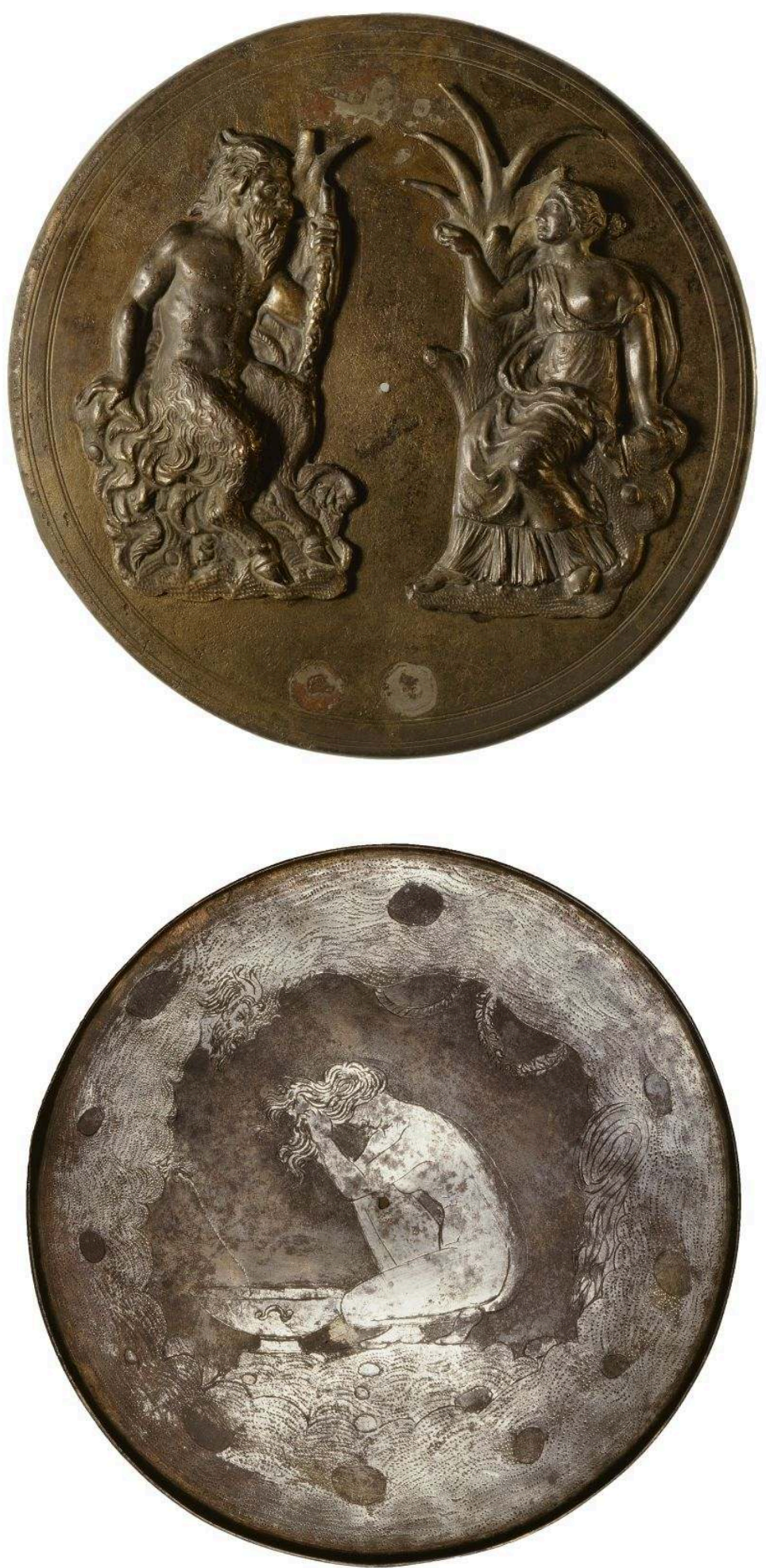

FIgS. 10A-B. BOX MIRROR, BERLIN, ANTIKENSAMMLUNg MISC. INV. 8148. PHOTOgRAPHER: JOHANNES LAURENTIUS.

CREDIT LINE: ANTIKENSAMMLUNG, STAATLICHE MUSEEN ZU BERLIN - PREUSSISCHER KULTURBESITZ. 


\section{Abbreviations}

\begin{tabular}{|l|l|}
\hline Agora & $\begin{array}{l}\text { The Athenian Agora: Results of Excavations Conducted by the American School of Classical Studies at } \\
\text { Athens, Princeton. }\end{array}$ \\
\hline ARV & J.D. BEAZLEY, Attic Red-Figure Vase-Painters, Oxford, $1963^{2}$. \\
\hline BAPD & Beazley Archive Pottery Database (online: http://www.beazley.ox.ac.uk). \\
\hline Para & $\begin{array}{l}\text { J.D. BEAZLEY, Paralipomena: Additions to Attic Black-figure Vase-painters and to Attic Red-figure } \\
\text { Vase-painters, Oxford, } 1971 .\end{array}$ \\
\hline
\end{tabular}

\section{BIBLIOGRAPHY}

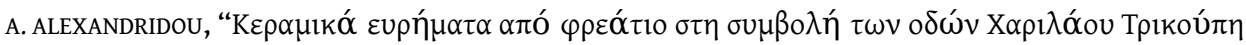

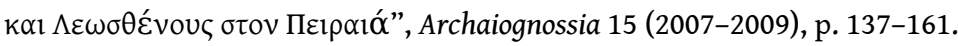

G. ANDERSON, Fairytale in the Ancient World, London, 2000.

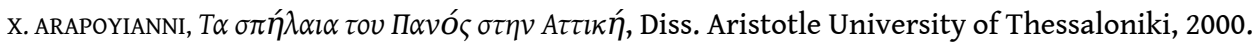
http://phdtheses.ekt.gr/eadd/handle/10442/13606. Date of consultation: 28.08.2018.

E.M.M. ASTON, Mixanthrôpoi: Animal-human Hybrid Deities in Greek Religion, Liège, 2011 (Kernos, suppl. 25).

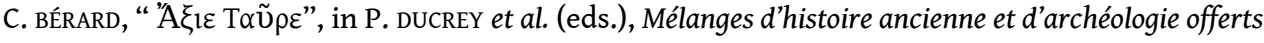
à Paul Collart, Lausanne, 1976, p. 61-73.

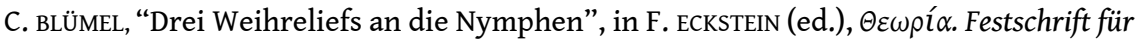
W.-H. Schuchhardt, Baden-Baden, 1960, p. 23-28.

J. BOARDMAN, “Pan”, in LIMC VIII (1997), p. 923-941.

Ph. BORGEAUD, The Cult of Pan in Ancient Greece (translated by K. Atlass, J. Redfield), Chicago, 1988 [French original: Recherches sur le dieu Pan, Genève, 1979].

F. BROMMER, “Pan im 5. und 4. Jahrhundert v. Chr.”, MarbJb 15 (1949-1950), p. 5-42.

R. BUXTON, Imaginary Greece, Cambridge, 1994.

C. CALAME, 1992. "Prairies et jardins intouchés", in A. MOREAU (ed.), L'Initiation. Actes du colloque international de Montpellier, 11-14 Avril 1991, vol. II, Montpellier, 1992, p. 103-118.

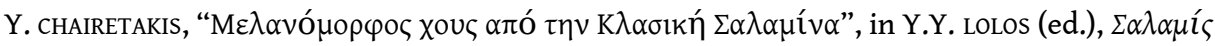

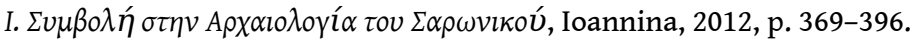

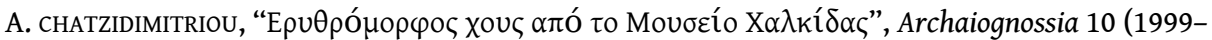
2000), p. 163-176.

G.S. CHIESA, A. PONTRANDOLFo (eds.), Mito e natura: dalla Grecia a Pompei, Milano, 2015. 
W.A.P. CHILDS, Greek Art and Aesthetics in the Fourth Century B.C., Princeton, 2017.

F. COLIVICCHI, "Lo specchio e lo strigile. Scambio di simboli e scambio fra i sessi", in F.-H. MASSA PAIRAULT (ed.), L'image antique et son interprétation, Rome, 2006, p. 277-300.

S. COLlin-BOUfFier, "Des vases pour les enfants", in M.-Chr. VILlANUeVA PUiG et al. (eds.), Céramique et peinture grecques, modes d'emploi. Actes du colloque international, École du Louvre 26-27-28 avril 1995, Paris, 1999, p. 91-96.

N. CUCUZZA, "Una rappresentazione arcaica di Pan a Creta? Note su una placchetta litica da Festòs", Creta Antica 10/I (2009), p. 301-319.

S. DALMON, "Entre l'humain et le divin : le statut intermédiaire des Nymphes dans la poésie épique grecque archaïque", in C. BOURHIS-MARIOTTI, M. GRUÉ (eds.), L'humain et les humanités, Travaux en cours 6 (2010), p. 38-49.

-, "Les Nymphes dans les rites du mariage", Cahiers « Mondes anciens » [online], 2 (2011), http:// mondesanciens.revues.org/400; DOI: 10.4000/mondesanciens.400. Date of consultation: 28.08.2018.

G.F. DE SIMONE, "Le donne alla fontana sui vasi attici a figure nere", in G. GRECO, B. FERRARA (eds.), Doni agli dei: il sistema dei doni votivi nei santuari. Atti del seminario di studi, Napoli 21 aprile 2006, Pozzuoli, 2008, p. 317-342.

A. DELIVORRIAS et al., “Aphrodite”, in LIMC II (1984), p. 2-151.

M. DETIENNE, “The Myth of 'Honeyed Orpheus' ”, in R.L. GORDON (ed.), Myth, Religion, and Society: Structuralist Essays, Cambridge, 1981, p. 95-109.

N. DIETRICH, Figur ohne Raum? Bäume und Felsen in der attischen Vasenmalerei des 6. und 5. Jahrhunderts v. Chr., Berlin, 2010 (Image and Context, 7).

_, “Lo spazio della natura e lo spazio dell'uomo", in CHIESA, PONTRANDOLFo (2015), p. 64-71.

A. DUNDES, “Interpreting 'Little Red Riding Hood' psychoanalytically”, in M. MCGLATHERY (ed.), The Brothers Grimm and Folktale, Urbana, 1988 [reprinted in A. DUNDES, (ed.), Little Red Riding Hood: A Casebook, Madison, 1989].

Ch.M. EDWARDS, Greek Votive Reliefs to Pan and the Nymphs, Diss. New York University, 1985.

P. ELLINGER, “Artémis, Pan et Marathon : mythe, polythéisme et événement historique”, in S. DES BOUVRIE (ed.), Myth and Symbol I: Symbolic Phenomena in Ancient Greek Culture (Papers from the First International Symposium on Symbolism at the University of Tromsø, June 4-7, 1998), Bergen, 2002 (Papers from the Norwegian Institute at Athens, 5), p. 313-332.

G. FERRARI, "The 'Anodos' of the Bride", in D. YATROMANOLAKIS, P. RoIlos (eds.), Greek Ritual Poetics, Washington, D.C., 2004, p. 245-260.

G. FERRARI, C.M. NIELSEN, K. OLSON (eds.), Chicago: The David and Alfred Smart Museum of Art, the University of Chicago, Chicago, 1998.

F. FRONTISI-DUCRouX, Le dieu-masque : une figure du Dionysos d'Athènes, Paris, 1991 (Images à l'appui, 4). M. GAIFMAN, "Visualized Rituals and Dedicatory Inscriptions on Votive Offerings to the Nymphs", Opuscula 1 (2008), p. 90-103.

R. GARLAND, Introducing New Gods. The Politics of Athenian Religion, London, 1992. 
E. GoossENS, “A Red-figure Chous with Satyrs from Thorikos”, in H. MUSSCHE (ed.), Studies in South Attica II, Gent, 1994, p. 115-120.

J.R. GREEN, “Choes of the Later Fifth Century”, ABSA 66 (1971), p. 189-228.

G. HAM, "The Choes and Anthesteria Reconsidered: Male Maturation Rites and the Peloponnesian Wars", in M.W. PADILLA (ed.), Rites of Passage in Ancient Greece: Literature, Religion, Society, Lewisburg, 1999, p. 201-218.

R. HAMILTON, Choes and Anthesteria, Ann Arbor, 1992.

G. HEDREEN, “' 'So-and-so kalē': A Brief Reexamination of the 'Beautiful' Woman”, in

D. YATROMANOLAKIS (ed.), Epigraphy of Art: Ancient Greek Vase-Inscriptions and Vase-Paintings, Oxford, 2016, p. 53-72.

A. HEINEMANN, “Chous”, in TheSCRA V.2.b (2005), s.v. Kultinstrumente, p. 351-354.

-, Der Gott des Gelages: Dionysos, Satyrn und Mänaden auf attischem Trinkgeschirr des 5. Jahrhunderts

v. Chr., Berlin, 2016.

T. HÖLSCHER, “ 'Is Painting a Representation of Visible Things?' Conceptual Reality in Greek Art: A Preliminary Sketch", in J. BINTLIFF, K. RUTTER (eds.), The Archaeology of Greece and Rome. Studies in Honour of Anthony Snodgrass, Edinburgh, 2016, p. 262-288.

U. HÜBINGER, “On Pan's Iconography and the Cult in the Sanctuary of Pan on the Slopes of Mount Lykaion", in R. HÄGG (ed.), The Iconography of Greek Cult in the Archaic and Classical Periods.

Proceedings of the First International Seminar on Ancient Greek Cult, organised by the Swedish Institute at Athens and the European Cultural Centre of Delphi, 16-18.11.1990, Liège, 1992 (Kernos, Suppl. 1), p. 189207.

S.C. HUMPHREYS, The Strangeness of Gods: Historical Perspectives on the Interpretation of Athenian Religion, Oxford, 2004.

C. ISLER-KERÉNYI, Civilizing Violence: Satyrs on 6th-century Greek Vases (trans. by E.Ch. de Sena), Fribourg/Göttingen, 2004.

-, Dionysos in Archaic Greece: An Understanding through Images (trans. by W.G.E. Watson), Leiden, 2007 (RGRW, 160).

-, Dionysos in Classical Athens: An Understanding through Images (trans. by A. Beerens), Leiden, 2015 (RGRW, 181).

M. Jost, Sanctuaires et cultes d'Arcadie, Paris, 1985 (Études Péloponnésiennes, 11).

L. KAHIL, “Artémis, Dionysos et Pan à Athènes”, Hesperia 60.4 (1991), p. 511-523.

A. KOSSATZ-DEISSMANN, “Choenfest”, in ThesCRA VI.1.b (2011), p. 41-45.

I. KRAUSKOPF, “Anthesterien-Bilder”, in ThesCRA VII.3 (2011), p. 113-117.

U. KREILINGER, Anständige Nacktheit: Körperpflege, Reinigungsriten und das Phänomen weiblicher Nacktheit im archaisch-klassischen Athen, Rahden/Westf., 2007.

J. LARSON, Greek Nymphs: Myth, Cult, Lore, Oxford, 2001.

-, Ancient Greek Cults, New York, 2007.

-, "A Land Full of Gods: Nature Deities in Greek Religion", in D. OGDEN, (ed.), A Companion to Greek Religion, Oxford, 2010, p. 56-70. 
H. LAVAGNE, Operosa Antra : recherches sur la grotte à Rome de Sylla à Hadrien Rome, 1988.

C.L. LAWTON, Agora XXXVIII: Votive Reliefs, Princeton, NJ, 2017.

A. LEBESSI, "Flagellation ou autoflagellation. Données iconographiques pour une tentative

d'interprétation", BCH 115 (1991), p. 99-123.

F. LISSARRAGUE, La cité des satyres : une anthropologie ludique, Athènes $V^{e}{ }^{e}-V^{e}$ siècles avant J.-C., Paris, 2013.

-, "Gli dei della natura", in CHIESA, PONTRANDOLFO (2015), p. 72-77.

L.H. LONSDALE, Dance and Ritual Play in Greek Religion, Baltimore, 1993.

N. MARQUARDT, Pan in der hellenistischen und kaiserzeitlichen Plastik, Bonn, 1995.

F. MAVRIDIS, J.T. JENSEN (eds.), Stable Places and Changing Perceptions: Cave Archaeology in Greece and Adjacent Areas, Oxford, 2013.

M. MENICHETTI, "La donna alla fontana. Charis e matrimonio sulle ciste prenestine", in I. colPo, I. FAVARETTO, F. GHEDINI (eds.), Iconografia 2005: immagini e immaginari dall'antichità classica al mondo moderno. Atti del convegno internazionale (Venezia, Istituto veneto di scienze lettere e arti, 26-28 gennaio 2005), Roma, 2006, p. 51-64.

H. METZGER, Les représentations dans la céramique attique du IV siècle, Paris, 1951.

M.B. MOORE, Agora XXX: Attic red-figured and white-ground pottery, Princeton, NJ, 1997.

Cl. MÜLLER, Kindheit und Jugend in der griechischen Frühzeit: eine Studie zur pädagogischen Bedeutung von Riten und Kulten, Giessen, 1990.

J. MYLONOPOULOS, "Natur als Heiligtum - Natur im Heiligtum", ARG 10.1 (2009), p. 51-84.

C. ORENSTEIN, Little Red Riding Hood Uncloaked: Sex, Morality, and the Evolution of a Fairy Tale, New York, 2002.

R. PARKER, Athenian Religion. A History, Oxford, 1996.

-, Polytheism and Society at Athens, Oxford, 2005.

G. PETRIDOU, Divine Epiphany in Greek Literature and Culture, Oxford, 2015.

S. PFISTERER-HAAS, "Mädchen und Frauen am Wasser. Brunnenhaus und Louterion als Orte der Frauengemeinschaft und der möglichen Begegnung mit einem Mann”, JDAI 117 (2002), p. 1-80.

-, "Mädchen und Frauen im Obstgarten und beim Ballspiel. Untersuchungen zu zwei vorhochzeitlichen Motiven und zur Liebessymbolik des Apfels auf Vasen archaischer und klassischer Zeit”, MDAI(A) 118 (2003), p. 139-195.

Ch. PILO, "Donne alla fontana e hydriai. Alcune riconsiderazioni iconografiche sul rapporto tra forma e immagine", in Ricerca e confronti 2010. Atti: giornate di studio di archeologia e storia dell'arte a 20 anni dall'istituzione del Dipartimento di Scienze Archeologiche e Storico-artistiche dell'Universita degli Studi di Cagliari (Cagliari, 1-5 marzo 2010), ArcheoArte suppl. to no. 1 (2012), p. 353-369.

C. PouzADOux, "La dualité du dieu bouc : les épiphanies de Pan à la chasse et à la guerre dans la céramique apulienne (seconde moitié du IV siècle av. J.-C.)”, Anthropozoologica 33-34, (2001), p. 11-21.

A. RUMPF, “Attische Feste - Attische Vasen”, BJb 161 (1961), p. 208-214. 
V. SABETAI, “The Poetics of Maidenhood: Visual Constructs of Womanhood in Vase-Painting", in S. SCHMIDT, J.H. OAKLEY (eds.), Hermeneutik der Bilder-Beiträge zu Ikonographie und Interpretation griechischer Vasenmalerei, München, 2009 (CVA Deutschland, Beih. IV), p. 103-114.

-, "The wedding vases of the Athenians: a view from sanctuaries and houses", Mètis N.S. 12 (2014), p. 51-79.

I. SCHEIBLER, "Bild und Gefäss. Zur ikonographischen und funktionalen Bedeutung der attischen Bildfeldamphoren", JDAI 102 (1987), p. 57-118.

S. SснміDт (2005), Rhetorische Bilder auf attischen Vasen: visuelle Kommunikation im 5. Jahrhundert

v. Chr., Berlin, 2005.

-, "Images of Statues on Attic Vases: The Case of the Tyrannicides", in V. NøRSKov (ed.), The World of Greek Vases, Rome, 2009, p. 219-237.

A. SCHWARZMAIER, Griechische Klappspiegel. Untersuchungen zu Typologie und Stil, Berlin, 1997 (MDAI[A] Beih. 18).

M. SEIFERT, Dazugehören: Kinder in Kulten und Festen von Oikos und Phratrie. Bildanalysen zu attischen Sozialisationsstufen des 6. bis 4. Jahrhunderts v. Chr., Stuttgart, 2011.

G. SIEBERT, "Imaginaire et images de la grotte dans la Grèce archaïque et classique”, Ktèma 15 (1990), p. 151-161.

F. SILVESTRELlI, "Donne al louterion nella ceramica apula e lucana”, in A. CALDERONE (ed.), Cultura e religione delle acque. Atti del Convegno interdisciplinare "Qui fresca l'acqua mormora..." (S. Quasimodo, Sapph. Fr. 2,5). Messina 29-30 marzo 2011, Roma, 2012, p. 113-124.

E. SIMON, “Amymone”, LIMC I (1981), p. 742-752.

N. SPINETO, Dionysos a teatro: il contesto festivo del dramma greco, Roma, 2005.

K. SPORN, "Höhlenheiligtümer in Griechenland", in Chr. FREVEL, H. VON HESBERG (eds.), Kult und Kommunikation: Medien in Heiligtümern der Antike, Wiesbaden, 2007, p. 39-62.

-, "Espace naturel et paysages religieux : les grottes dans le monde grec", RHR 227.4 (2010), p. 553-571.

-, "Mapping Greek Sacred Caves: Sources, Features, Cults" in MAVRIDIS, JENSEN (2013), p. 202-216.

E.M. STERN, “Kinderkännchen zum Choenfest”, in Th. LORENZ (ed.), Thiasos: sieben archäologische Arbeiten, Amsterdam, 1978 (Castrum Peregini, 132.3), p. 27-37.

J. STROSZECK, “Das Grab des Eupheros”, in Die griechische Klassik. Idee oder Wirklichkeit: eine Ausstelung im Martin-Gropius-Bau, Berlin 1. März-2. Juni 2002 und in der Kunst- und Austellungshalle der Bundesrepublik Deutschland, Bonn 5. Juli-6. Oktober 2002, Mainz, 2002, p. 468-472.

K. TUChelT, "Pan und Pankult in Kleinasien”, MDAI(I) 19/20 (1969-1970), p. 223-236.

Y. USTINOVA, Caves and the Ancient Greek Mind: Descending Underground in the Search for Ultimate Truth, Oxford, 2009.

-, Divine Mania: Alteration of Consciousness in Ancient Greece, London, 2017.

G. VAN HOORN, Choes and Anthesteria, Leiden, 1951.

E. vouTIRAS, "Pan en Macédoine", in M. KALAITZI, P. PASCHIDIS, Cl. ANTONETTI, A.-M. GUIMIER-SORBETS

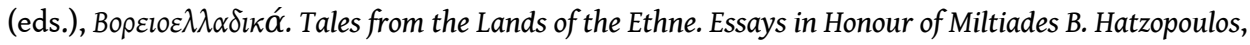


Athens, 2018 (National Hellenic Research Foundation / Institute of Historical Research, Meletemata 78), p. 397-411.

H. WALTER, Pans Wiederkehr: der Gott der griechischen Wildnis, München, 1980.

J.M. WICKENS, The Archaeology and History of Cave Use in Attica, Greece from Prehistoric Through Late Roman Times, Diss. Indiana University, 1986.

A. ZAMPITI, "Schisto Cave at Keratsini (Attika): The Pottery from Classical Through Roman Times", in MAVRIDIS, JENSEN (2013), p. 306-318.

Ph. ZAPHIROPOULOU, "Ein Grabrelief aus Paros", in S. BUZZI et al. (eds.), Zona archeologica: Festschrift für Hans Peter Isler zum 60. Geburtstag, Bonn, 2001, p. 481-486.

\section{NOTES}

1. On Pan see Borgeaud (1988); GARLAND (1992), p. 58-63; ELLINGER (2002), esp. p. 327-330; PARKer (1996), p. 163-168; LARSON (2010), p. 63-64; ASTON (2011), p. 109-120; 272-277 and passim; PETRIDOU (2015), p. 201-205; VOUTIRAS (2018).

2. Athens, Benaki Museum, inv. no. 38145; gift of Mr. James Hutchinson. Provenance unknown, but said to be from Eleusis. Date: ca. $430 \mathrm{BC}$. Height to top of handle: $8.9 \mathrm{~cm}$. Diameter of base: $5.6 \mathrm{~cm}$. Maximum diameter: $6.9 \mathrm{~cm}$. Part of its neck and the entire mouth are missing and restored in plaster; surface abraded on its reserved areas. Thin glaze, gray-greenish at the back side of the vase. Interior glazed. Dilute glaze is used to denote rocky texture. The vase's rather heavy foot finds some resemblance with examples in GREEN (1971), esp. p. 215, no. 4, fig. 10.2 ("The Sydney Class"). I am indebted to the late director of the Benaki Museum, Angelos Delivorrias, and to curator Eirene Papageorgiou for publication permits and amenities for study, to Greta Ham for discussion on choes, to Judy Barringer, Vinciane Pirenne-Delforge and JanMathieu Carbon for valuable comments and to the last mentioned for checking also my English text. For the acquisition of photos I thank the staff in the Museums at Berlin, Athens (Acropolis) and Cleveland, esp. Agnes Schwarzmaier, Nina Zimmermann and Angelika Kouveli. A version of this article was discussed in the study-seminar "Into the Wild", which was co-organised by Vasso Zachari and Thomas Galoppin at the EHESS, Paris (23.7.2018).

3. For the iconography and iconology of caves and rocky landscapes see BÉRARD (1976), p. 61-65; EDWARDS (1985), p. 59-63; SIEBERT (1990); DIETRICH (2010).

4. Pan is rendered as a half-figure emerging from the rocks on a few late fifth- or early fourthcentury vases and on the Archandros relief (430-420 BC): see BROMMER (1949-1950), p. 28-29, figs. 37-38; p. 32, fig. 43; GAIFMAN (2008), p. 91-94, fig. 2. In these examples Pan is an upright position (Fig. 4). For the iconography of Pan see further MARQUARDT (1995), esp. p. 281-308; BOARDMAN (1997); POUZADOUX (2001).

5. See, e.g., the krater Syracuse 44291 (ARV 1041, 9; BAPD 213532) by the Polygnotan Group depicting Amymone in the posture of filling a vase but where no fountain is drawn.

6. For the hydriaphoros 's gesture, cf. a cup at Brauron, ARV 827, 1 (BAPD 210255).

7. ZAPHIROPOULOU (2001). We should be precluded from unanimously identifying all short-haired females in art as slaves.

8. See, e.g., SABETAI (2009), p. 108, fig. 3; p. 112, fig. 10 (ARV 1137, 35 and 1139, 4; BAPD 215072 and 215095); add an oinochoe in the antiquities market (Para 454, 44 bis; BAPD 276115). For shorthaired women by this painter in other scenes see ARV 1136, 11; 1137, 28 and 34 (BAPD 215048, 215065 and 215071). Stylistic similarities of this kind may suggest that our vase was painted by the Hasselmann Painter or an associate. 
9. For reliefs to Pan and the nymphs see EDWARDS (1985); LAWTON (2017), p. 64-68. Note that the worshippers depicted are usually men.

10. See BOARDMAN (1997), p. 931; LARSON (2001), p. 155-156.

11. For epiphanic Pan, see PETRIDOU (2015), p. 201-205.

12. ARV 550, 1; 1659 (BAPD 206276). For Pan's bestial sexuality, see BORGEAUD (1988), p. 74-80; ASTON (2011), p. 183.

13. For the cultic cave in Greek culture, see BUXTON (1994), p. 104-108; SPORN (2007); MYLONOPOULOS (2009), p. 56-59; USTINOVA (2009), esp. p. 55-58; SPORN (2010); ASTON (2011), p. 153-160; 164-168; SPORN (2013). For the archaeology of Attic caves see WICKENS (1986); ARAPOYIANNI (2000); ZAMPITI (2013).

14. SABETAI (2014), p. 68-69.

15. Krateriskoi in the caves: ZAMPITI (2013), p. 307-309. For the association of Artemis and Pan, see KAHIL (1991), p. 517-518; ELLINGER (2002).

16. Pan in the Peloponnese: JOST (1985); HÜBINGER (1992); LARSON (2007), p. 151. For a typological forerunner of Pan from the Artemis Orthia sanctuary, see MARQUARDT (1995), p. 281-282. For Pan in other areas, such as Boeotia, Crete and Macedonia, see BORGEAUD (1988), p. 174-175; cucuzZA (2009) and Voutiras (2018). For Pan's boisterous dance as a component of initiatory rites, see BORGEAUD (1988), p. 151, n. 118; LONSDALE (1993), p. 262.

17. For a hydriaphoros holding her empty vase like our female see the chous in Athens, Kerameikos Museum 4290 (BAPD 2947).

18. For springs in the wilderness and for the contrast between wild water and city water in the testimonia, see BUXTON (1994), p. 109-113, esp. 109, n. 132 (citing E. Hipp. 225-227). For rocky fountains, an iconographic peculiarity characterizing the encounter between Achilles and Polyxene as an illegitimate one in marginal space, see DIETRICH (2010), p. 334-341.

19. For the semantics of orchards in vase-painting and in literature, see PFISTERER HAAS (2003) and CALAME (1992) respectively.

20. For Little Red Riding Hood, see DUNDES (1988); ORENSTEIN (2002). For versions of this tale as well as Beauty and the Beast in ancient literature see ANDERSON (2000), p. 92-97; 169 and 69-71 respectively. For fairytales focusing on maidens and water see ibidem, p. 176-178.

21. For the fear instilled by Pan, see UsTinova (2017), p. 227-234.

22. For women at the fountain in Attic imagery, see PFISTERER HAAS (2002). For further treatment in various areas, time-periods and art-media, see selectively MENICHETTI (2006); DE SIMONE (2008); SABETAI (2009); SILVESTRELLI (2012); HEDREEN (2016), p. 60-66.

23. KREILINGER (2007).

24. For conceptual reality, see HÖLSCHER (2016). The fawns appearing in fountain scenes are iconographic signs that function as the symbolic parallel of the maiden on the animal level: SABETAI (2009), p. 105.

25. PILO (2012) connects more narrowly the late archaic images of hydrophoriai with the Anthesteria.

26. For accounts from modern Greece and Italy, see BUXTON (1994), p. 112; HEINEMANN (2016), p. 288, n. 693.

27. Young Amymone is commonly pictured as encountering Poseidon at such a spot: see, e.g., ARV 1401, 2 (BAPD 250143). Rocky springs are rare in non-mythological scenes but are favoured by the Hasselmann Painter: see n. 8 above.

28. ISLER-KERÉNYI (2004); LISSARRAGUE (2013), p. 191-215. The occasional anthropomorphism of Pan in classical art should be understood in this context too.

29. On Pan's cave, see BORGEAUD (1988), p. 50-52; LAVAGNE (1988), p. 57-72. ASTON 2011, p. 113-114. 
30. A socio-historic approach saw the official installation of the new god in the wild clefts of the Acropolis, halfway between mortals and gods, in the context of the Cleisthenic reforms which sought to mix the rural with the urban population of Attica. Yet, this view does not account for Pan's association with the cave rather than a temple in the $5^{\text {th }}$ century BC: LAVAGNE (1988), p. 61. See further MARQUARDT (1995), p. 281, n. 2.

31. For land in remotis and the gods controlling it, see BORGEAUD (1988), p.60; PETRIDOU (2015), p. 195-228.

32. The latter imagery occurs on mirrors, see, e.g., BOARDMAN (1997), p. 932, no. 181; SCHWARZMAIER (1997), p. 258-259, no. 59, pl. 83.2 (ca. 280 BC). For women washing themselves with hydriai, a vase-shape used also in bridal preparations, or at the louterion, in the art of $4^{\text {th }}$ century $\mathrm{BC}$, see CHILDS (2017), p. 230-261 with previous bibliography.

33. For travellers thought of as prone to epiphanic manifestations of divinities, such as Pan, at the dangerous hour of the noon, see PETRIDOU (2015), p. 207-214, esp. 210-214.

34. DETIENNE (1981), p. 102-103; LARSON (2001), p. 3-4; 109-110; DALMON, (2010), p. 38-39; DALMON (2011).

35. BORGEAUD (1988), p. 155-156. For Pan and the nymphs, see further LARSON (2001), p. 96-98.

36. LAVAGNE (1988), p. 67-70.

37. BORGEAUD (1988), p. 172.

38. SIEBERT (1990), p. 156, fig. 1.

39. For caves and Dionysiac festivities, see BÉRARD (1976).

40. LISSARRAGUE (2015), p. 76. DIETRICH (2015), p. 66-69 argues that elements of nature are more emphatically present and detailed when the figures are in the wild.

41. BORGEAUD (1988), p. 178, notes that these associations are iconographic, not cultic. For Pan's Dionysiac links see also the Homeric Hymn to Pan, 45-47.

42. HÜBINGER (1992), p. 190-194, figs. 1-3; CVA Amsterdam, Allard Pierson Museum 5, pl. 268, 5 (BAPD 4916; ca. 490 BC).

43. BOARDMAN (1997), p. 924, no. 5, pl. 612 (ca. 470 BC). For the tangent iconographies of Pan and the Dionysiac thiasos, see LISSARRAGUE (2013), p. 114-117.

44. BOARDMAN (1997), p. 924, no. 3, pl. 612 (BAPD 352238; ca. 490 BC).

45. For Pan and the Aphrodisian milieu see BOARDMAN (1997), p. 933, nos. 191-196, pl. 626. DELIVORRIAS et al. (1984), p. 113, nos. 1158-1159, pl. 115; 113-114, no. 1160; 128, nos. 1343-1353, pls. 131-132.

46. FERRARI, NIELSEN, OLSON (1998), p. 72-73 (480-450 BC).

47. CVA Leipzig, Antikenmuseum der Universität 3, pl. 74, 5 and 75, 5 (BAPD 214332).

48. For scenes of the sacred wedding in the $4^{\text {th }}$ century BC see METZGER (1951), p. 133-136.

49. BOARDMAN (1997), p. 936, no. 244, pl.632; SIMON (1981), p. 747, no.63, pl.604; 749, no. 79; HEINEMANN (2016), p. 284-293. For hierogamia and other scenes witnessed by Pan (Judgment of Paris; birth of Dionysos), see WALTER (1980), p. 76-80, figs. 61-66.

50. BORGEAUD (1988), p. 145-146; LEBESSI (1991), p. 117-120; LONSDALE (1993), p. 265-266. FERRARI (2004). The model bridal female may be mortal or divine (e.g. Aphrodite or Persephone, both identified by inscriptions).

51. BORGEAUD (1988), p. 58-60.

52. CVA Cleveland 2 (USA 35), pl. 102 (Pagenstecher Class; 350-300 BC).

53. For the sides of this mirror, see BOARDMAN (1997), p. 932, no. 181, pl. 625, and DELIVORRIAS et al. (1984), p. 102, no. 994, pl. 96. The scene recalls that on an Attic cup where a satyr with sexual intentions is depicted instead of Pan (Gravisca 73.10683 and 73.11895; BAPD 24130). The theme spreads further to South Italian pottery; for an early example, see, e.g., a louterion scene 
(COLIVICCHI [2006], p. 285, fig. 15), where Pan watches a bride engaged in hair-binding, a nuptial gesture that is popular in wedding scenes by the Washing Painter.

54. BLÜMEL (1960), p. 24-25, figs. 1-2; TUCHELT (1969-1970), p. 234, no. 19; p. 235, no. 27; LARSON (2001), p. 201-202, fig. 4.13.

55. For the Anthesteria, see HUMPHREYs (2004), 223-275; SPINETO (2005), p. 13-123; PARKER (2005), p. 290-316.

56. For a chous from Athens (Peiraeus street; $3^{\text {rd }}$ Ephorate of Antiquities inv. no. 3500) depicting a boy at the brink of adolescence solemnly tasting wine before the mask of Dionysos and overseen by a priest and a child holding a wreathed chous, see BAPD 28128.

57. SPINETO (2005), p. 31-32; 36-37; 45-47; $110 \mathrm{ff}$. offers a thorough discussion of testimonia that may suggest involvement of older children, including girls, in the festivities. For the Anthesteria as a milestone in life that was of equal standing to marriage, birth and ephebate see the revealing, though late, Iobakchoi inscription ( $2^{\text {nd }}$ century AD, IG II ${ }^{2} 1368$ [LSCG 51] 130).

58. On various issues regarding the choes-jugs and their relationship to the Anthesteria, see MÜLLER (1990), p. 64-79; HAMILTON (1992); MOORE (1997), p. 41-42; HAM (1999); PARKER (2005), p. 297301; SCHMIDT (2005), p. 152-221; KRAUSKOPF (2011); KOSSATZ-DEISSMANN (2011); SEIFERT (2011), p. 108 138; HEINEMANN (2005); HEINEMANN (2016), p. 467-487. The small choes production peaks in the last third of the $5^{\text {th }} \mathrm{c}$. BC. Their frequent occurrence in tombs may be due to the high child mortality caused by the Peloponnesian War: HAM (1999).

59. For choes depicting girls of various ages, see MÜLLER (1990), p. 74-75; see further VAN HOORN (1951), e.g. figs. 272; 278-279; 311; 384; 488; 495; 522 and 539. Some examples are listed in GREEN (1971) (esp. p. 215-216). For choes from tombs of girls in the West, see collin-BOUfFIER (1999), p. 93.

60. The chous' total height would be ca. $9 \mathrm{~cm}$ : see n. 2, above.

61. Grapes are clearly an iconographic sign in the images, as these are not fruits of the Spring and could not have been physically present at the Anthesteria: SPINETO (2005), p. 29.

62. HAMILTON (1992), p. 116-118, thinks that the stereotyped scenes on small choes depict the festival from a child's viewpoint.

63. For satyrs, see GoOSSENS (1994). For goat-riding and for Eros with a toy instead of a child, see CVA Baltimore, Walters Art Gallery 1, pl. 33, 1-5 (BAPD 3414 and 10221); for a chariot of goats see CHATZIDIMITRIOU (1999-2000).

64. Cf. SPINETO (2005), p. 27-28; PARKER (2005), p. 306-312, both based on FRONTISI-DUCROUX (1991) for the methodology of analyzing Dionysiac ritual imagery.

65. For the ritualization of wine-drinking see PARKER (2005), p. 315-316. For flower and wine metaphors in the Anthesteria, see SPINETO (2005), p. 33-35.

66. ISLER-KERÉNYI (2007); ISLER-KERÉNYI (2015).

67. For the rarity of girls on beakers, see PARKER (2005), p.300. Female participation in the Anthesteria was important in other rituals, such as the sacred marriage of Dionysos to the Basilinna and perhaps also the swinging ritual of the Aiora (PARKER [2005], p. 183-184; 301-302; 380 ), which pertains to the prenuptial sphere. The Anthesteria seems to have been all-inclusive, since slaves also participated in the formal or private feasts: SPINETO (2005), p. $110 \mathrm{ff}$; cf. further ibidem, p. 45-47 for the possible participation also of women.

68. Although most beakers come from tombs, their discovery in settlements (e.g., ALEXANDRIDOU [2007-2009]; CHAIRETAKIS [2012]) and sanctuaries in Attica and elsewhere precludes their a priori funerary use.

69. RUMPF (1961), p. 213-214; STERN (1978), p. 32-33; SCHEIBLER (1987), p. 110-111. Note that small choes could be given also to adolescents: STROSZECK (2002).

70. Note that the chous from the Peiraeus street depicting ephebic initiation at the Anthesteria is $21 \mathrm{~cm}$ high; see n. 56, above. 
71. For a bridal female see, e.g., CVA Los Angeles, County Museum of Art 1, pl. 35, 1-2 (BAPD 4626). For the wedding motif of Eros binding the bride's nuptial shoe see ARV 1323, 36 (BAPD 220589). For a possible depiction of Poseidon and the nymph Amymone on a fourth-century chous from Eleusis, see Simon 1981, p. 749, no. 87. For a chous with a musical bride tentatively labelled Helen, see ARV 1324, 38 (BAPD 220591). For a girl washing herself, see ARV 1249, 16 (BAPD 216952).

72. See SCHMIDT (2009), p. 230-234, for further discussion on the Tyrannicides, a theme that occurs with some frequency on choes.

73. PETRIDOU (2015), p. 205.

74. SPINETO (2005), p. 41-42, discusses domestication of wine as the theme underpinning a myth recalled at the Anthesteria, namely that of Ikarios, who fell victim to those who drunk unmixed the newly invented wine.

\section{ABSTRACTS}

The paper analyzes a rare Attic red-figure chous of the fifth century BC, which depicts Pan and a young woman holding a hydria in a wild natural environment. The bestial god appears, emerging from his cave, while the maiden strides towards a rocky spring surprised at the encounter. The natural landscape of the scene is remarkable, as the hydriaphoros is not framed by architectural elements denoting urban culture, such as a fountain-house, but by various types of rocky formations, one of which is sacralized by the rural deity inhabiting it. Pan's rocky abode instead of a man-made cult-place and the spring instead of a fountain-house imply that the maiden is away from the civilized space of her polis and oikos and in the potentially frightful realm controlled by wild divinities, one of whom is famous for the fear created by his shriek. The discussion focuses on the meaning of hydriaphorai at the fountain or the spring, an iconographical and cultural topos referring metaphorically to maidenhood; and on Pan as a deity of mixed nature (human and bestial) who is an appropriate companion of nubile girls at the brink to maturation. Pan's cave-abode and the rocky spring construct a conceptual space of eschatiai which visualizes the liminality of the maiden's condition from maidenhood to becoming a numphè, i.e. at the threshold of marriage. The image activates elements drawn from three semantic realms, namely maidenhood, interstitial divinities and the Anthesteria.

L'article analyse un chous attique à figures rouges du v viècle av. J.-C., qui représente Pan et une jeune femme tenant une hydrie dans un environnement sauvage. Le dieu émerge d'une grotte, tandis que la jeune femme, surprise par cette rencontre, s'éloigne vers une source rocheuse. Le paysage naturel de la scène est remarquable, et la quête de l'eau n'est pas associée à des éléments architecturaux reliés à une culture urbaine, mais à différents types de formations rocheuses, dont l'une est sacralisée par la présence de la divinité rurale qui y réside. La demeure rocheuse de Pan, en lieu et place d'un lieu de culte fait de main d'homme, et la source, en lieu et place d'une fontaine construite, impliquent que la jeune femme se situe hors de l'espace civilisé de sa cité et de sa maison. Elle évolue dans un lieu potentiellement effrayant, contrôlé par des divinités sauvages, dont l'une est célèbre pour les peurs générées par ses hurlements. La discussion porte sur le sens de cette quête de l'eau à la fontaine ou à la source, un topos iconographique et culturel qui renvoie métaphoriquement à la jeunesse des filles. On se penche aussi sur Pan en tant que divinité mixte (humaine et bestiale) qui est le compagnon adéquat des filles nubiles. La grotte qui abrite Pan et la source rocheuse construisent un espace conceptuel d'eschatiai donnant à voir la 
liminalité de la condition de la jeune femme qui, de jeune fille, devient une numphè au seuil du mariage. L'image active des composantes issues de trois champs sémantiques: la féminité juvénile, les divinités intersticielles et les Anthestéries.

\section{AUTHOR}

\section{VICTORIA SABETAI}

Research Centre for Antiquity of the Academy of Athens

vsabetai@academyofathens.gr 